\title{
Comparative Analysis of Customer Satisfaction on Islamic and Conventional Banks in Malaysia
}

\author{
Norma Md. Saad \\ Departmentt of Economics, Kulliyyah of Economics and Management Sciences \\ International Islamic University Malaysia \\ 53100 Gombak, Selangor, Darul Ehsan, Malaysia \\ Tel: 60-3-6196-4649 E-mail: norma@iium.edu.my
}

Received: June 2, $2011 \quad$ Accepted: July 25, $2011 \quad$ Published: January 1, 2012

doi:10.5539/ass.v8n1p73

URL: http://dx.doi.org/10.5539/ass.v8n1p73

\begin{abstract}
Customer satisfaction is critically important for banks to stay competitive as the customer is the ultimate source of income for any organization. Islamic banking system and conventional banking system are considered as rival systems working in the same banking industry. In order for Islamic banks to compete successfully with conventional banks, Islamic banks must give extremely high consideration to their primary customers. Whenever either Islamic banks or conventional banks offer any product or service, its success depends upon the customer satisfaction towards that product or service. This study examines the level of customer satisfaction on Islamic banks as well as conventional banks in Malaysia. It also investigates the relationship between different demographic variables and the satisfaction of customers. A sample of 1,153 respondents from various cities representing different states in Malaysia was selected. The results in this study suggest that customers are mostly satisfied with the quality of services which include competency, friendliness, and efficiency of the staff of the Islamic and conventional banks.
\end{abstract}

Keywords: Customer satisfaction, Islamic banking, Conventional banking, Malaysia

\section{Introduction}

The existence of Islamic banking operation in Malaysia can be traced back to 1963 when Tabung Haji or the Pilgrims Management and Fund Board was established by the government. The establishment shows the concern of the government at that time towards the religious consciousness of the Muslim community in Malaysia. In fact, Tabung Haji which is a specialized financial institution provides a very systematic mobilization of funds from Muslim savers in order to perform pilgrimage as well as encourage them to participate in investment opportunities indirectly. Tabung Haji is considered to be the first of its kind in the world (Mohammed Seidu, 2002).

Based on that experience, the government of Malaysia spearheaded a well-coordinated Islamic banking system, which can be divided into three different stages. The first stage is from 1983-1992, which is known as the familiarization process whereby Bank Islam Malaysia Berhad (BIMB) was established and works in accordance with Syariah principles. Under this roof, Islamic Banking Act (IBA) was officially enacted. The second stage took place from 1993 to 2003 with the aim of creating conducive environment and competitive advantage for Islamic banks. At the same time, the government tried to give BIMB ample time to capture larger market share. The third stage is known as the period of financial liberalization (BNM, 2004) which commenced from 2004 until present. This is the right time to create awareness among the public especially Muslims, of the benefits of Islamic banking. Under this phase, conventional banks are allowed to offer Islamic banking services by setting up "Islamic windows" or also known as "Islamic banking scheme". By July 2008, Bank Negara Malaysia reported that there are 22 commercial banks in the banking industry, 13 Islamic banks, 15 investment banks and 2 financial institutions (http:www.bnm.gov.my/index.php?ch=13\&cat=banking).

Customer satisfaction is important for banks to stay competitive as the customer is the ultimate source of income for any organization. Islamic banking system and conventional banking system are considered as rival systems working in the same banking industry. Conventional banking system is based on interest rate whereas Islamic 
banking system is based on profit-sharing. Conventional banks were established much earlier in Malaysia compared to Islamic banks. This certainly indicates that Islamic banks have to really compete with conventional banks.

In order for Islamic banks to compete successfully with conventional banks, Islamic banks must give extremely high consideration to their primary customers. Whenever either Islamic banks or conventional banks offer any product or service, its success depends upon the customer satisfaction towards that product or service. This study examines the level of customer satisfaction on Islamic banks as well as conventional banks. The objectives of this study are as follows:

1) To evaluate customer satisfaction on Islamic and conventional banks in Malaysia

2) To make comparisons on the customer satisfaction level of Islamic banks and conventional banks operating in Malaysia.

This paper is organized as follows. The second part presents the literature review, and the third part discusses the methodology of the study. Part 4 presents the research findings and analysis, and followed by conclusion in Part 5 .

\section{Literature Review}

The establishment of Islamic banks has grown rapidly since it was first introduced four decades ago. Since then, the Islamic banking system has spread to the whole world and is accepted by both Muslims and non-Muslims. Islamic banks can no longer be regarded as business organizations established to fulfill religious obligations, but as business entities competing side by side with the conventional banks in attracting customers and retaining them. Studies have shown that there are many factors that affect customer satisfaction toward a particular bank. Among the common factors used to measure customer satisfaction are service delivery (fast and efficient), convenience (location and parking facilities). A study conducted by Dusuki and Abdullah (2007) on 52 different branches of Islamic banks in Malaysia found that customer satisfaction normally depends on the quality of services provided by Islamic banks. According to Dusuki and Abdullah (2007), the quality of services include factors such as treating customers politely and with respect; staff ability to uphold trust and confidence; effective and efficient in handling transactions; and competency of staff in handling customers banking needs.

Osman, Ali, Zainuddin, Wan Rashid, Jusoff (2009) conducted a similar study to examine customers satisfaction on Islamic banking in Malaysia. In this study, Osman, Ali, Zainuddin, Wan Rashid, Jusoff (2009) measured customer satisfaction in six different variables, namely, compliance, assurance, reliability, tangibles, empathy, and responsiveness based on CARTER model developed by Othman an Owen (2001). The study also compares the service quality and customer satisfaction between full-fledged Islamic banks and conventional banks offering Islamic banking products and services. The study found that compliance to Islamic principles is the most significant criteria why customers choose to patronize Islamic banks. The study also ranked Bank Islam Malaysia Berhad at the top under the compliance attribute.

Khattak and Ur-Rehman (2010) carried out a study on customer satisfaction and awareness of Islamic banking system in Pakistan. They investigated the relationship between different demographic variables and the satisfaction and awareness of customers. The study found that most of the customers adopt Islamic banking because of religious reasons, but there are other factors that motivate customers to patronize the Islamic banking system such as, efficiency, confidentiality, business hours, etc. In addition, the study also found that income level has significant relationship with most of the customer satisfaction variables.

Another study conducted to examine customer satisfaction on Islamic bank was by Naser, Jamal, and Al-Khatib (1999). Naser, Jamal, and Al-Khatib (1999) carried out a survey to measure customer satisfaction and preferences on Islamic banking in Jordan. In this study, they made an attempt to assess the degree of customer awareness and satisfaction towards an Islamic bank in Jordan. A sample of 206 respondents was used in the study. The results of the study revealed a certain degree of satisfaction of many of the Islamic banks facilities and products. In addition, the respondents expressed their dissatisfaction with some of the Islamic banks services. Naser, Jamal, and Al-Khatib (1999) reported that although the respondents indicated that they are aware of a number of specific Islamic financial products like Murabaha, Musharaka and Mudaraba, the respondents show that they do not deal with these products.

Cohen, Gan, Yong and Choong (2006) undertook a study on customer satisfaction looking at bank customer retention in New Zealand. They examined the impact of several retention-relevant constructs that influence consumers' decisions to stay with or leave their banks in New Zealand. These constructs were rated by customers as having strong effects on loyalty to their banks. The results of their study revealed that the most 
important constructs were customer satisfaction, followed by corporate image and switching barriers. There was also evidence in the study that customers' age groups and level of education contributed to explaining respondents' decision to stay with their current banks.

Nupur (2010) carried out an analysis on e-banking and customer satisfaction in Bangladesh. The study tested five quality service variables, namely, reliability, responsiveness, assurance, empathy, and tangibles based on SERVQUAL model, in e-banking to explore the relationship between service quality and customer satisfaction. Nupur (2010) found that the five service quality variables are the core service quality dimensions for customer satisfaction in e-banking. In addition, the study also found that reliability, responsiveness, and assurance have more contribution to satisfy the customers of e-banking in Bangladesh.

\section{Research Methodology}

\subsection{Sample}

In this study, a total of 1,153 respondents were selected from various cities representing different states in Malaysia. Out of these 1,153 respondents, 579 are customers of Islamic banks and 574 are customers of conventional banks. We have targeted respondents from different level of education. The total number of male and female respondents are 529 and 623, respectively.

\subsection{Instrument}

The data for this study were obtained through survey questionnaires distributed to respondents at 50 different branches of Islamic banks and 97 different branches of conventional banks in different states in Malaysia. The questionnaire is divided into two sections. The first section includes the demographic information of the respondent (age, gender, race, religion, marriage status, and level of education). In the second section, respondents were asked to indicate the level of satisfaction on a particular bank based on a five-point Likert-type scale, ranging from "excellent" to "very poor". Most of the variables included in the questionnaire have been adapted from previous studies on customer satisfaction in banking (Khattak and Rehman, 2010; Dusuki and Abdullah, 2006; Nupur, 2010).

\subsection{Procedure}

The questionnaires were filled by account holder and other customers of Islamic and conventional banks. The Islamic banks included in the study are Bank Islam, Bank Muamalat, Bank Rakyat, CIMB Islamic, Al-Rajhi Bank, and Public Islamic Bank. The conventional banks included in the survey are Maybank, CIMB, Public Bank, HSBC Bank, Bank Simpanan National, RHB Bank, Hong Leong Bank, Bumiputera Commerce Bank, and Ambank. The questionnaires were distributed to respondents at 50 different branches of Islamic banks and 97 branches of conventional banks in 12 different states of Malaysia; Selangor, Negeri Sembilan, Johor, Kuala Lumpur, Pahang, Pulau Pinang, Melaka, Perak, Terengganu, Kelantan, Sabah, and Sarawak.

The total time period taken to conduct the survey was three months (December 2009 to February 2010). The questionnaires were distributed with the help of enumerators. A total of 1215 questionnaires were distributed and out of these the usable questionnaires were 1153 .

\subsection{Analysis}

This study measures customer satisfaction towards the Islamic and conventional banking services. Customer responses obtained from the survey were analyzed using SPSS. The responses within different factor groups were tested for internal consistency and reliability using Cronbach alpha tests. In order to measure the level of customer satisfaction on Islamic and conventional banks, Friedman test was conducted to rank 7 factors which influence customer satisfaction. SPSS was also used to carry out Chi-square test to check the relationship between demographic variables and the customer satisfaction level.

\section{Research Findings}

\subsection{Profile of Respondents}

The personal profile of the respondents is shown in Table 1 . Table 1 shows that majority ( 86.1 percent) of the respondents are between the age of 21-40 years. The results in Table 1 also indicate that the majority of the respondents are highly educated, with approximately 20 percent holding college diploma or certificates and around 58 percent holding a bachelor's degree.

\subsection{Descriptive Statistics}

Table 2 shows the mean values depicting the customers' satisfaction on Islamic and conventional banks. The results in Table 2 suggest the main factors on which the customers of Islamic and conventional banking are 
generally satisfied. As far as the mean values are concerned, customers are fairly satisfied on efficiency of service, personnel friendliness, personnel competency, physical facilities, strategic location, and accessibility by public transportation. In the case of Islamic banking, customers are less satisfied on the availability of parking space with the mean value of 2.8359 compared to a mean value of 3.1864 for the conventional banks.

\subsection{Relationship between Customers' Satisfaction Level and Demographic Variables}

In order to comprehend on the relationship between the customer satisfaction level and the demographic aspects, we performed Chi-square test. The results are displayed in Tables 3-4. The results in Tables 3-4 demonstrate that gender and ethnicity have significant relationship with efficiency of service. In the case of conventional bank, ethnicity is found to have a significant relationship with banks personnel friendliness. According to Othman and Owen (2001), quality in service is not just ensuring conformity to standards, but taking into account in service on the diversity of customers, the behavior and expectations of the customer being served and to customize the delivery accordingly. A study conducted by Hui, Chern and Othman (2008) comparing three ethnic groups in two different industries in Malaysia found that service quality in the eastern culture is different from the western culture especially when personalization is deemed to be the most important dimension of service evaluation.

For conventional banking, the result in Table 4 shows that there is a significant relationship between age and availability of parking space, whereas in the case of Islamic banks, the results demonstrate a significant relationship between age, ethnicity, and education level with the availability of parking space. It could also be observed in Table 3 that there exists a significant relationship between physical facilities and ethnicity.

\subsection{Ranking of Customer Satisfaction}

The results on the ranking of customer satisfaction are summarized in Tables 5-6. The results in Tables 5-6 indicate that customers of both Islamic and conventional banks are highly satisfied with the banks' competent personnel, friendliness and efficiency of service. The findings of this study concur well with those of Dusuki and Abdullah (2007) who found that personnel factor is one of the major factors influencing customers in making decision to patronize a particular bank. Abbas et al. (2003) who conducted a study on customers' choice in selecting Islamic financing products reported that incompetence and lack of courtesy of Islamic bank's personnel was the main reason why customers averted Islamic finance.

In addition to the staff factor, customers of Islamic and conventional banks are also satisfied with the location of their banks. In Table 5, Islamic banks are ranked as number 3 as being strategically located, whereas in Table 6 , the conventional banks are ranked as second in strategic location.

The results in Tables 5-6 show that customers of both Islamic and conventional banks are less satisfied with the accessibility of public transportation to go to the bank, bank physical facilities, and availability of parking space. The above results imply that both Islamic and conventional banks not only have to pay attention to the staff factor (courteous, competent, friendly, and efficient), other factors such as access to public transport, physical facilities, and availability of parking space need to be given extra attention. This is particularly important for Islamic banks since the score for availability of parking space is the lowest compared to six other factors. The score for availability of parking space for Islamic banks is also lower compared to that of the conventional banks.

\section{Conclusion}

The main objective of this study is to measure the customer satisfaction level towards Islamic and conventional banks. Our study shows that most of the customers of the Islamic and conventional banks are highly educated. The results of the study also show that majority of the customers are in the age of 21 to 40 years.

The most important fact revealed by this study is that customer satisfaction of a particular bank often depends on the quality of services offered. The results in this study suggest that customers are mostly satisfied with the quality of services which include competency, friendliness, and efficiency of the staff of both Islamic and conventional banks. The important insight identified on the ranking of banks' customer satisfaction implies the need for Islamic banks to improve its service quality since it is a crucial success factor affecting the competitiveness of an organization.

In addition to improving quality of service, the findings of the study also revealed that Islamic banks need to make tremendous improvement in providing suitable and adequate parking space for their customers. Furthermore, another important issue which requires improvement on the part of Islamic banks, is that Islamic banks need to upgrade the physical facilities, for example, providing a more comfortable waiting area or lounge for customers who patronize a particular Islamic bank so that the customers are comfortable while waiting for the bank's staff to attend to their banking needs. As there were only six Islamic banks and nine conventional 
banks (out of 17 Islamic banks and 24 conventional banks operating in Malaysia) included in the analysis, the findings may only be just indicative and definitely not conclusive of the banking industry as a whole. Furthermore, since recently more Islamic banks have been established, further comprehensive studies are needed to examine the level of customer satisfaction on Islamic banks vis-à-vis the conventional banks

\section{Acknowledgements}

This paper is an outcome of a research project funded by International Islamic University Malaysia. The author would like to thank the University for generously funding the research.

\section{References}

Abbas, S. Z. M., Hamid, M. A. A., Joher, H. and Ismail, S. (2003). Factors that determine consumers' choice in selecting Islamic financing products. Paper presented at the International Islamic Banking Conference, Prato.

Bank Negara Malaysia, BNM. (2004). Annual Report.

Cohen, D., Gan, C., Yong, H. H. A. and Choong, E. (2006). Customer satisfaction: a study of bank customer retention in New Zealand, Commerce Division, Discussion Paper No. 109, Lincoln University, Canterbury.

Dusuki, A. W. and Abdullah, N. I. (2007). Why do Malaysian customers patronize Islamic banks? International Journal of Bank Marketing, 25(3), 142-160. http://dx.doi.org/10.1108/02652320710739850

Hui, Chern and Othman. (2008). Development of service quality dimensions in Malaysia -The case of a multicultural society, AFBE 2008 Conference Papers. [Online] Available: http://www.afbe.biz/main/wp-content/uploads/AFBEConfPapers2008.pdf

Khattak, N. A. and Ur-Rehman, K. (2010). Customer satisfaction and awareness of Islamic banking system in Pakistan. African Journal of Business Management, 4(5), 662-671.

Mohammed Seidu, A. (2002). Cost-competitiveness of Fixed Liability Financing: A Study of Bank Islam Malaysia Berhad's Financing Techniques. Unpublished Ph.D thesis, University Tun Abdul Razak, Malaysia.

Naser, K., Jamal, A. and Al-Khatib, K. (1999). Islamic banking: a study of customer satisfaction and preferences in Jordan. International Journal of Bank Marketing, 17(3), 135-151. http://dx.doi.org/10.1108/02652329910269275

Nupur, J. M. (2010). E-banking and customers' satisfaction in Bangladesh: An analysis. International Review of Business Research Papers, 6(4), 145-156.

Osman, I., Ali, H., Zainuddin, A., Wan Rashid, W. E. and Jusoff, KJ. (2009). Customers satisfaction in Malaysian Islamic banking. International Journal of Economics and Finance, 1(1).

Othman, A. and Owen, L. (2001). Adopting and measuring customer service quality (SQ) in Islamic banks: a case in Kuwait Finance House. International Journal of Islamic Financial Services, 3(1), 1-26. 
Table 1. Respondents' profile

\begin{tabular}{|c|c|c|c|c|c|}
\hline Variables & Frequency & Percentage & Variables & Frequency & Percentage \\
\hline Age & & & Academic qualification & & \\
\hline 20 or less & 72 & 6.2 & Less than high school & 14 & 0.3 \\
\hline $21-30$ years & 873 & 75.7 & High school & 147 & 13.7 \\
\hline $31-40$ years & 120 & 10.4 & Certificate/Diploma & 225 & 19.5 \\
\hline \multirow[t]{3}{*}{41 or more } & 88 & 7.6 & Bachelor's degree & 673 & 58.4 \\
\hline & & & Master & 86 & 7.5 \\
\hline & & & $\mathrm{PhD}$ & 8 & 0.7 \\
\hline Gender & & & Marital status & & \\
\hline Male & 529 & 46.0 & Married & 293 & 25.4 \\
\hline \multirow[t]{2}{*}{ Female } & 623 & 54.0 & Not married & 829 & 71.9 \\
\hline & & & Single parent & 31 & 2.7 \\
\hline Religion & & & Ethnicity & & \\
\hline Islam & 1063 & 92.2 & Malay & 920 & 79.8 \\
\hline Christian & 31 & 2.7 & Chinese & 59 & 5.1 \\
\hline Buddhist & 28 & 2.4 & Indian & 41 & 3.6 \\
\hline Hindu & 30 & 2.6 & Other & 133 & 11.5 \\
\hline Other & 1 & 0.1 & & & \\
\hline
\end{tabular}

Table 2. Descriptive statistics

\begin{tabular}{|l|c|c|c|c|c|c|}
\hline & \multicolumn{3}{|c|}{ Islamic banks } & \multicolumn{3}{c|}{ Conventional banks } \\
\hline & N & Mean & Std. Deviation & N & Mean & Std. Deviation \\
\hline $\begin{array}{l}\text { Efficiency of } \\
\text { service }\end{array}$ & 579 & 3.6114 & .89555 & 574 & 3.6916 & .75245 \\
\hline $\begin{array}{l}\text { Personnel } \\
\text { friendliness }\end{array}$ & 579 & 3.7496 & .82004 & 574 & 3.7091 & .76850 \\
\hline $\begin{array}{l}\text { Personnel } \\
\text { competency }\end{array}$ & 579 & 3.7807 & .75691 & 574 & 3.8415 & .64796 \\
\hline $\begin{array}{l}\text { Availability of } \\
\text { parking space }\end{array}$ & 579 & 2.8359 & 1.05671 & 574 & 3.1864 & 1.34791 \\
\hline $\begin{array}{l}\text { Physical } \\
\text { facilities }\end{array}$ & 579 & 3.4352 & .94697 & 574 & 3.6185 & .84532 \\
\hline $\begin{array}{l}\text { Strategic } \\
\text { location }\end{array}$ & 579 & 3.7323 & .92589 & 574 & 3.9059 & 1.87149 \\
\hline $\begin{array}{l}\text { Accessibility by } \\
\text { public } \\
\text { transportation }\end{array}$ & 579 & 3.4231 & 1.03681 & 574 & 3.6585 & .95544 \\
\hline
\end{tabular}


Table 3. Relationship between customer satisfaction and the demographic variable of Islamic banks

\begin{tabular}{|l|c|c|c|c|c|c|c|c|c|c|c|c|}
\hline & \multicolumn{2}{|c|}{ Age } & \multicolumn{2}{|c|}{ Gender } & \multicolumn{2}{c|}{ Religion } & \multicolumn{2}{c|}{ Ehnicity } & \multicolumn{2}{c|}{ Marital Satus } & \multicolumn{2}{c|}{ Education Level } \\
& $\chi^{2}$ & Sig. & $\chi^{2}$ & Sig. & $\chi^{2}$ & Sig. & $\chi^{2}$ & Sig. & $\chi^{2}$ & Sig. & $\chi^{2}$ & Sig. \\
\hline Efficiency of service & 18.814 & 0.278 & 9.057 & $0.060^{*}$ & 6.47 & 0.898 & 28.305 & $0.005^{* *}$ & 12.612 & 0.126 & 22.685 & 0.538 \\
\hline Personnel friendliness & 16.499 & 0.419 & 3.420 & 0.490 & 6.077 & 0.912 & 12.750 & 0.387 & 7.932 & 0.440 & 15.396 & 0.909 \\
\hline Personnel competency & 16.348 & 0.429 & 6.396 & 0.171 & 5.953 & 0.918 & 11.317 & 0.502 & 10.867 & 0.209 & 23.690 & 0.479 \\
\hline $\begin{array}{l}\text { Avallability of parking } \\
\text { space }\end{array}$ & 25.130 & $0.068 *$ & 3.228 & 0.520 & 17.899 & 0.119 & 25.269 & $0.014 *$ & 7.970 & 0.436 & 34.178 & $0.082^{*}$ \\
\hline Physical facilities & 21.037 & 0.177 & 3.931 & 0.415 & 8.457 & 0.749 & 18.611 & $0.098 *$ & 9.929 & 0.270 & 21.800 & 0.591 \\
\hline \begin{tabular}{l} 
Strategic location \\
\hline
\end{tabular} & 12.478 & 0.711 & 3.859 & 0.425 & 3.988 & 0.984 & 12.358 & 0.417 & 2.082 & 0.978 & 26.616 & 0.323 \\
\hline $\begin{array}{l}\text { Accessibility by public } \\
\text { transportation }\end{array}$ & 18.635 & 0.288 & 3.678 & 0.451 & 13.134 & 0.359 & 13.041 & 0.366 & 11.225 & 0.189 & 26.712 & 0.318 \\
\hline
\end{tabular}

(*** significant at $1 \%, * *$ significant at $5 \%, *$ significant at $10 \%$ )

Table 4. Relationship between customer satisfaction and the demographic variable of conventional banks

\begin{tabular}{|c|c|c|c|c|c|c|c|c|c|c|c|c|}
\hline & \multicolumn{2}{|c|}{ Age } & \multicolumn{2}{|c|}{ Gender } & \multicolumn{2}{|c|}{ Religion } & \multicolumn{2}{|c|}{ Ehnicity } & \multicolumn{2}{|c|}{ Marital Satus } & \multicolumn{2}{|c|}{ Education Leve } \\
\hline & $\chi^{2}$ & Sig. & $x^{2}$ & Sig. & $x^{2}$ & Sig. & $x^{2}$ & Sig. & $\chi^{2}$ & Sig. & $x^{2}$ & Sig. \\
\hline Efficiency of service & 13.549 & 0.632 & 16.626 & $0.034^{* *}$ & 8.775 & 0.922 & 7.649 & 0.812 & 5.325 & 0.722 & 16.645 & 0.676 \\
\hline Personnel friendliness & 15.324 & 0.501 & 9.082 & 0.335 & 4.663 & 0.997 & 25.374 & $0.013^{* *}$ & 9.753 & 0.283 & 20.213 & 0.445 \\
\hline Per sonnel competency & 9.972 & 0.618 & 5.223 & 0.516 & 8.093 & 0.778 & 7.846 & 0.550 & 7.392 & 0.286 & 21.358 & 0.126 \\
\hline $\begin{array}{l}\text { Availability of parking } \\
\text { space }\end{array}$ & 51.266 & $0.000^{* * *}$ & 12.979 & 0.225 & 17.525 & 0.619 & 19.225 & 0.204 & 10.848 & 0.369 & 32.835 & 0.135 \\
\hline Physical facilities & 15.175 & 0.512 & 2.329 & 0.969 & 12.961 & 0.676 & 9.890 & 0.626 & 12.720 & 0.122 & 11.741 & 0.925 \\
\hline Strategic location & 17.047 & 0.650 & 4.260 & 0.935 & 15.902 & 0.723 & 11.907 & 0.686 & 4.600 & 0.916 & 28.155 & 0.301 \\
\hline $\begin{array}{l}\text { Accessibility by public } \\
\text { transportation }\end{array}$ & 17.691 & 0.343 & 5.734 & 0.677 & 11.066 & 0.805 & 10.981 & 0.531 & 5.995 & 0.648 & 15.215 & 0.764 \\
\hline
\end{tabular}

(*** signi ficant at $1 \%, * *$ significant at $5 \%,{ }^{*}$ significant at $\left.10 \%\right)$ 
Table 5. Ranking of customer satisfaction (Islamic banks)

\begin{tabular}{lllll}
\hline & Arithmetic mean* & Std. dev. & Mean rank & Ranking \\
\hline Personnel competency & 3.7807 & 0.7569 & 4.55 & 1 \\
Personnel friendliness & 3.7496 & 0.8200 & 4.49 & 2 \\
Strategic location & 3.7323 & 0.9259 & 4.47 & 3 \\
Efficiency of service & 3.6114 & 0.8956 & 4.19 & 4 \\
Accessibility by public transportation & 3.4231 & 1.0368 & 3.85 & 5 \\
Physical facilities & 3.4352 & 0.9470 & 3.84 & 6 \\
Avvilability of parking space & & 1.0567 & 2.62 & 7 \\
N & 57.8359 & & & \\
Chi-square & & & & \\
Degree of freedom (df) & 477.959 & & & \\
Asymp. Sig. & 6 & & & \\
Note: *Mean values - scoring 1 = very poor, $5=$ excell ent & & & & \\
\hline
\end{tabular}

Table 6. Ranking of customer satisfaction (conventional banks)

\begin{tabular}{lllll}
\hline & Arithmetic mean* & Std. dev. & Mean rank & Ranking \\
\hline Personnel competency & 3.8415 & 0.6480 & 4.45 & 1 \\
Strategic location & 3.9059 & 1.8715 & 4.42 & 2 \\
Personnel friendliness & 3.7091 & 0.7685 & 4.11 & 3 \\
Efficiency of service & 3.6916 & 0.7525 & 4.11 & 4 \\
Accessibility by public transportation & 3.6585 & 0.9554 & 4.05 & 5 \\
Physical facilities & 3.6185 & 0.8453 & 3.89 & 6 \\
Availability of parking space & 3.1864 & 1.3479 & 2.97 & \\
N & 574 & & & \\
Chi-square & & & & \\
Degree of freedom (df) & 257.867 & & & \\
Asymp. Sig. & 6 & & & \\
Note: *Mean values - scoring 1 = very poor; $5=$ excellent & 0.000 & & & \\
\hline
\end{tabular}

